\title{
Evaluation of a Microfluidic Device for the Electrochemical Determination of Halide Content in Ionic Liquids
}

\author{
R. Ge, ${ }^{\dagger}$ R. W. K. Allen, ${ }^{\ddagger}$ L. Aldous, ${ }^{\dagger}$ M. R. Bown, ${ }^{\ddagger}$ Nicola Doy, ${ }^{\S}$ C. Hardacre, ${ }^{\star \dagger}$ J. M. Maclnnes, ${ }^{\star *}$ \\ G. McHale, $\$$ and M. I. Newton ${ }^{\S}$ \\ QUILL Research Centre, School of Chemistry and Chemical Engineering, Queen's University Belfast, Belfast, BT9 5AG, U.K., \\ Department of Chemical \& Process Engineering, University of Sheffield, Newcastle St, Sheffield S1 3JD, U.K., and School of \\ Science \& Technology, Nottingham Trent University, Clifton Lane, Nottingham NG11 8NS, U.K.
}

A microfluidic device designed for electrochemical studies on a microliter scale has been utilized for the examination of impurity levels in ionic liquids (ILs). Halide impurities are common following IL synthesis, and this study demonstrates the ability to quantify low concentrations of halide in a range of ILs to levels of $\sim 5 \mathrm{ppm}$, even in ILs not currently measurable using other methods such as ion chromatography. To validate the mixer device, the electrochemistry of ferrocene was also examined and compared with spectroscopic and bulk electrochemistry measurements. An automated "sample preparation, delivery, and calibration" method was developed, and the chip successfully used for linear sweep, cyclic voltammetry (under both quiescent and steady-state flowing conditions), square wave voltammetry, and differential pulse voltammetry. An effective method of electrochemically cleaning the electrodes is also presented.

In the past decade, the use of ionic liquids (ILs) as alternative solvents and media for a wide range of applications has expanded significantly in both academia, as well as in industry. ${ }^{1-5}$ The importance of impurities in ILs has been recognized by many researchers in this area with water, halide, and metal impurities from the synthesis of the ILs being the most prevalent. These affect both physical and chemical properties of the media, for example, drastically increasing viscosity ${ }^{6}$ and thermal conductivity, ${ }^{7}$ while also poisoning catalytic reactions. ${ }^{8}$ Additionally, Jacquemin et al. have quantified the effect of halide and water content

\footnotetext{
* To whom correspondence should be addressed. E-mail: c.hardacre@qub.ac.uk (C.H.), j.m.macinnes@sheffield.ac.uk (J.M.M.).

$\dagger$ Queen’s University Belfast.

* University of Sheffield.

$\S$ Nottingham Trent University.

(1) Ionic Liquids in Synthesis, 2nd ed.; Wasserscheid, P., Welton, T., Eds.; WileyVCH Verlag: Weinheim, 2007.

(2) Pârvulescu, V. I.; Hardacre, C. Chem. Rev. 2007, 107, 2615-2665.

(3) Silvester, D. S.; Compton, R. G. Z. Phys. Chem. 2006, 220, 1247-1274.

(4) Harper, J. B.; Kobrak, M. N. Mini-Rev. Org. Chem. 2006, 3, 253-269.

(5) Plechkova, N. V.; Seddon, K. R. Chem. Soc. Rev. 2008, 37, 123-150.

(6) Seddon, K. R.; Stark, A.; Torres, M. J. Pure Appl. Chem. 2000, 72, 22752287.

(7) Ge, R.; Hardacre, C.; Jacquemin, J.; Nancarrow, P.; Rooney, D. W. J. Chem. Eng. Data 2008, 53, 2148-2153.

(8) Anderson, K.; Goodrich, P.; Hardacre, C.; Rooney, D. W. Green Chem. 2003, 5, 448-453.
}

on the density of a wide range of ILs as a function of pressure and temperature, highlighting the importance of being able to measure their concentration accurately. ${ }^{9,10}$ It should be noted that typical commercial samples contain between 10 and $1000 \mathrm{ppm}$ of halide from their synthesis. ${ }^{11}$ The purity strongly determines their cost because of the loss of IL during multistage purification.

With respect to halide content, although commonly used, the technique of using the "silver nitrate" is only qualitative and is insufficient to examine ILs for many applications. ${ }^{12}$ However, a number of other methods have been demonstrated for the quantification of halide in ILs, although it is important to note that many have only been investigated for halide in water-miscible ILs with few studies aimed at more hydrophobic ILs, such as those based on tetraalkylphosphonium cations or trispentafluoroethyltrifluorophosphate $\left([\mathrm{FAP}]^{-}\right)$anions. These techniques include Volhard (silver nitrate) and chloride-selective electrodes, ${ }^{6,13}$ spectrophotometry using fluorescent indicators, ${ }^{14}$ ion chromatography (IC) ${ }^{15-19}$ ICP-MS,${ }^{20}$ capillary zone electrophoresis, ${ }^{21} \mathrm{XPS},{ }^{22}$ and electrochemistry. ${ }^{23-25}$ IC has been demonstrated to be a versatile technique for the determination of halides in both hydrophobic and hydrophilic ILs. For example, Villagrán et al.

(9) Jacquemin, J.; Ge, R.; Nancarrow, P.; Rooney, D. W.; Costa Gomes, M. F.; Pádua, A. A. H.; Hardacre, C. J. Chem. Eng. Data 2008, 53, 716-726.

(10) Jacquemin, J.; Nancarrow, P.; Rooney, D. W.; Costa Gomes, M. F.; Husson, P.; Majer, V.; Pádua, A. A. H.; Hardacre, C. J. Chem. Eng. Data 2008, 53, 2133-2143.

(11) Electrodeposition from Ionic Liquids; Endres, F., MacFarlane, D., Abbott, A., Eds.; Wiley-VCH Verlag: Weinheim, 2008.

(12) Hilgers, C.; Wasserscheid, P. In Ionic Liquids in Synthesis; Wasserscheid, P., Welton, T., Eds.; Wiley-VCH Verlag: Weinheim, 2007.

(13) Mateus, N. N. M.; Branco, L. C.; Lourenço, N. M. T.; Afonso, C. A. M. Green Chem. 2003, 5, 347-352.

(14) Anthony, J. L.; Maginn, E. J.; Brennecke, J. F. J. Phys. Chem. B 2001, 105, 10942-10949.

(15) Billard, I.; Moutiers, G.; Labet, A.; El Azzi, A.; Gaillard, C.; Mariet, C.; Lutzenkirchen, K. Inorg. Chem. 2003, 42, 1726-1733.

(16) Anderson, J. L.; Ding, J.; Welton, T.; Armstrong, D. W. J. Am. Chem. Soc. 2002, 124, 14247-14254.

(17) Villagrán, C.; Deetlefs, M.; Pitner, W. R.; Hardacre, C. Anal. Chem. 2004, $76,2118-2123$.

(18) Hao, F.; Haddad, P. R.; Ruther, T. Chromatographia 2008, 67, 495-498.

(19) Stepnowski, P.; Markowska, A. Aust. J. Chem. 2008, 61, 409-413.

(20) McCamley, K.; Warner, N. A.; Lamoureux, M. M.; Scammells, P. J.; Singer, R. D. Green Chem. 2004, 6, 341-344.

(21) Berthier, D.; Varenne, A.; Gareil, P.; Digne, M.; Lienemann, C.-P.; Magna, L.; Olivier-Bourbigou, H. Analyst 2004, 129, 1257-1261.

(22) Silvester, D. S.; Broder, T. L.; Aldous, L.; Hardacre, C.; Crossley, A.; Compton, R. G. Analyst 2007, 132, 196-198. 


\begin{tabular}{|c|c|c|c|c|}
\hline method & $\begin{array}{l}\text { approximate mass } \\
\text { of IL needed } / \mathrm{g}^{a}\end{array}$ & $\mathrm{LOQ} / \mathrm{ppm}^{a}$ & comments & reference \\
\hline Volhard & 0.3 & ca. 400 & IL must be water miscible & 6 \\
\hline Spectrophotometric & $\mathrm{n} / \mathrm{a}$ & ca. 300 & $\begin{array}{l}\text { IL must not quench } \\
\text { fluorescence }\end{array}$ & 13 \\
\hline Chloride selective electrode & 0.1 & ca. 20 for water miscible samples & $\begin{array}{l}\text { Reported for water and } \\
\text { ethanol miscible IL samples. } \\
\text { Note for ethanol soluble } \\
\text { samples minimum values of } \\
1000 \text { ppm have been } \\
\text { reported }\end{array}$ & 6 \\
\hline Ion chromatography & 0.1 & $4-8$ & $\begin{array}{l}\text { IL must dissolve in a } \\
\text { minimum of } 40 \% \text { acetonitrile } \\
+60 \% \mathrm{H}_{2} \mathrm{O} \text {; Long retentions } \\
\text { times are found for highly } \\
\text { polarizable anions such as } \\
{\left[\mathrm{NTf}_{2}\right]^{-},[\mathrm{FAP}]^{-} \text {in general }} \\
\text { limiting turnaround of } \\
\text { samples }\end{array}$ & 16 \\
\hline ICP-MS & 0.1 & ca. 0.01 & $\begin{array}{l}\text { Low LOQ was found for water } \\
\text { soluble IL but problems } \\
\text { were encountered for water } \\
\text { immiscible ILs due to low } \\
\text { solubility. }\end{array}$ & 19 \\
\hline Capillary zone electrophoresis & 0.2 & ca. 5 & $\begin{array}{l}\text { Water miscible and } \\
\text { immiscible ILs studied. }\end{array}$ & 20 \\
\hline Macro-scale Electrochemistry & 1.0 & $2-30$ & $\begin{array}{l}\text { The viscosity of the IL to be } \\
\text { analyzed limits the detection } \\
\text { limit but high viscosity } \\
\text { materials can be diluted with } \\
\text { molecular solvents. }\end{array}$ & 23 \\
\hline Microscale Electrochemistry & $<0.05$ & $5-17$ & & this work \\
\hline
\end{tabular}

\footnotetext{
${ }^{a}$ Mass of IL used determines the LOQ of the techniques where the sample needs to be diluted. The LOQ values shown in the table are for the mass of IL summarized.
}

showed that limits of quantification (LOQ) of $<8$ ppm were possible for both 1-butyl-3-methyl imidazolium hexafluorophophate $\left(\left[\mathrm{C}_{4} \mathrm{mim}\right]\left[\mathrm{PF}_{6}\right]\right)$ and tetrafluoroborate $\left(\left[\mathrm{C}_{4} \mathrm{mim}\right]\left[\mathrm{BF}_{4}\right]\right)$ ILs. ${ }^{16}$ However, for ILs containing large polarizable anions, such as bis $\{$ (trifluoromethanesulfonyl)imide $\}\left(\left[\mathrm{NTf}_{2}\right]^{-}\right)$the analysis time can be long and relatively large amounts of IL $(\sim 100$ $\mu \mathrm{L})$ are needed. In addition, the samples must have a significant solubility in water-organic solvent mixtures as they cannot be analyzed without dilution.

Spectrophotometry and electrochemical techniques such as linear sweep (LSV), square wave (SWV), and cathodic stripping voltammetry have been used to quantify the chloride concentration in both water miscible and water immiscible ILs. Both methods can be scaled down to chip level, although limits of quantification below $400 \mathrm{ppm}$ have not been achieved by spectrophotometry. ${ }^{6}$ For electrochemical techniques good sensitivity has been reported for both LSV and SWV in $\left[\mathrm{C}_{4} \mathrm{mim}\right]\left[\mathrm{PF}_{6}\right],\left[\mathrm{C}_{4} \mathrm{mim}\right]\left[\mathrm{BF}_{4}\right]$, and $\left[\mathrm{C}_{4} \mathrm{mim}\right]\left[\mathrm{NTf}_{2}\right]$, with levels of quantification ranging between 7 and $30 \mathrm{ppm}$, the value being dependent upon the viscosity of the $\mathrm{IL}^{23}$ Cathodic stripping voltammetry was shown to be capable of detecting sub parts per million levels of halide, with limits of quantification reported to be $\sim 0.3 \mathrm{ppm}$ for $\left[\mathrm{C}_{4} \mathrm{mim}\right]\left[\mathrm{PF}_{6}\right],\left[\mathrm{C}_{4} \mathrm{mim}\right]\left[\mathrm{BF}_{4}\right]$, and $\left[\mathrm{C}_{4} \mathrm{mim}\right]\left[\mathrm{NTf}_{2}\right]{ }^{23}$ In general, the electrochemistry techniques employed to date require a significant volume of IL (at least $\sim 1000 \mu \mathrm{L}$ ) for each sample, and multiple samples are required to produce calibration curves. In addition, each sample takes a significant amount of time to measure, including electrode preparation, multiple sample preparation, cleaning and reassembly of set up, and the measurement. The techniques used, to date, for ILs and the LOQ/mass used in each with limitations are summarized in Table 1. It should be noted that all methods currently used routinely require a calibration curve; therefore, preparation times for the analysis of the IL samples can vary significantly depending on the dilutions required and the number of data points on the calibration curve.

This paper examines the use of a microfluidic device incorporating a mixer and electrochemical cell to provide an automated voltammetric method of determination of halide content in ILs using a small volume of IL. A number of considerations are required to be taken into account and assessed prior to implementation of the technology. Because of the small area of the electrodes, the limits of detection and quantification need to be examined in detail. Moreover, the issue of measurement reproducibility is important with both electrode cleanliness and sample to sample contamination, important considerations for assembled devices. Most polycrystalline electrodes require either periodic resurfacing or pretreatment to maintain optimal and reproducible behavior. ${ }^{26}$ For the device used herein, platinum is used as the electrode material which is commonly used for both macro- and

(23) Xiao, L.; Johnson, K. E. J. Electrochem. Soc. 2003, 150, E307-E311.

(24) Villagrán, C.; Banks, C. E.; Hardacre, C.; Compton, R. G. Anal. Chem. 2004, 76, 1998-2003.

(25) Sun, H.; Yu, L.; Jin, X.; Hu, X.; Wang, D.; Chen, G. Z. Electrochem. Commun. 2005, 7, 685-691.

(26) Swain, G. M. In Handbook of Electrochemistry; Zoski, C. G., Ed.; Elsevier: Amsterdam, 2007. 
microscale electrochemistry. ${ }^{27}$ However, it is also prone to oxide formation and the adsorption of foreign species; thus, reproducible electrode handling is required to generate a reproducible response. As well as physical resurfacing by the use of abrasive materials, electrochemical cleaning is a method of surface regeneration. Typically, for platinum, this takes the form of deliberate oxide formation at oxidative potentials followed by oxide dissolution at reductive potentials to yield a regenerated $\mathrm{Pt}$ surface. ${ }^{26}$ However, this requires the original introduction of a potential oxide forming compound, such as water. Therefore, while this method is favored for aqueous studies, its use in ideally anhydrous or non-aqueous electrochemical studies is limited. An alternative mechanism is the generation of gas bubbles, or the generation of chemically reactive reagents to clean the electrode surface. This issue has been addressed in detail in this paper.

Because of their high viscosity and low diffusivity compared with commonly employed molecular solvents, few studies have examined the use of microchannel devices with ILs. For example, de Mello et al. use electric current through IL in a microchannel to provide heating and, thereby, temperature control on a microfluidic device. ${ }^{28}$ Chen et al. examined the mixing of a fluorescent dye in IL streams in a chain of special microchannel elements. ${ }^{31}$ However, to date microchannel devices incorporating electrochemical cells and their use for analytical purposes have not been examined.

The preparation of known concentrations for calibration purposes in this work used an automated procedure employing syringes, syringe drives, and a mixer device. The precision of the mixture composition produced by the device is demonstrated in the paper. A further aspect of accurate measurement of a particular sample solution is deposition of a pure aliquot of that sample in the volume of the measurement cell. In order for pre-existing sample liquid not to contaminate the deposited sample adequate volume flushing of the supply path with the new sample liquid must be achieved.

\section{EXPERIMENTAL SECTION}

Materials and Synthesis. 1-Butyl-3-methylimidazolium chloride $\left(\left[\mathrm{C}_{4} \mathrm{mim}\right] \mathrm{Cl}\right)$, 1-butyl-1-methylpyrrolidinium chloride ([ $\left.\left.\mathrm{C}_{4} \mathrm{mPyrr}\right] \mathrm{Cl}\right), 1-$ butyl-3-methylimidazolium bis $\{$ (trifluoromethyl)sulfonyl\}imide $\left(\left[\mathrm{C}_{4}\right.\right.$ mim $\left.]\left[\mathrm{NTf}_{2}\right]\right)$, 1-butyl-3-methylimidazolium trifluoromethanesulfonate $\left(\left[\mathrm{C}_{4} \mathrm{mim}\right][\mathrm{OTf}]\right)$, and 1-butyl-3-methylimidazolium tetrafluoroborate $\left(\left[\mathrm{C}_{4} \mathrm{mim}\right]\left[\mathrm{BF}_{4}\right]\right)$ were prepared in house using standard literature methods. ${ }^{29-31}$ ILs based on the trispentafluoroethyltrifluorophosphate $\left([\mathrm{FAP}]^{-}\right)$ anion were obtained from Merck. Trihexyltetradecylphosphonium bis $\{$ (trifluoromethyl) sulfonyl $\}$ imide $\left(\left[\mathrm{P}_{666,14}\right]\left[\mathrm{NTf}_{2}\right]\right)$ was prepared from $\left[\mathrm{P}_{666,14}\right] \mathrm{Cl}$ supplied by Cytec. The halide content of ILs was determined using suppressed ion chromatography (IC), ${ }^{16}$ with the exception of the $\left[\mathrm{P}_{666,14}\right]^{+}$and $[\mathrm{FAP}]^{-}$based ILs which cannot currently be measured using IC. The water

(27) Manica, D. P.; Mitsumori, Y.; Ewing, A. G. Anal. Chem. 2003, 75, 45724577.

(28) de Mello, A. J.; Habgood, M.; Lancaster, N. L.; Welton, T.; Wootton, R. C. R. Lab Chip 2004, 4, 417-419.

(29) Earle, M. J.; Katdare, S. P.; Seddon, K. R. Org. Lett. 2004, 6, 707-710.

(30) Bonhôte, P.; Dias, A. P.; Papageorgiou, N.; Kalyanasundaram, K.; Grätzel, M. Inorg. Chem. 1996, 35, 1168-1178.

(31) Suarez, P. A. Z.; Einloft, S.; Dullius, J. E. L.; de Souza, R. F.; Dupont, J. J. Chim. Phys. 1998, 95, 1626-1639. content was determined by volumetric Karl Fischer titration using a Mettler Toledo DL31 titrator. All ILs were found to have halide concentrations below the detection limit of suppressed ion chromatography (ca. $5 \mathrm{ppm}$ ). All ILs were dried under high vacuum at $70{ }^{\circ} \mathrm{C}$ prior to use, until the resulting IL contained a residual water content of $<0.01 \mathrm{wt} \%$. The ILs were stored in a $\mathrm{N}_{2}$-filled glovebox where all solutions were prepared and the reservoirs were loaded.

Instrumentation. All experiments and automated syringe loading were carried out in an air-conditioned room (temperature $\left.20 \pm 1{ }^{\circ} \mathrm{C}\right)$.

Macro-scale electrochemical determination of chloride content was carried out in glass cells using $2 \mathrm{~g}$ of IL, and performed with a three-electrode arrangement with a platinum (1.6 $\mathrm{mm}$ diameter) working electrode and two platinum wires as counter and pseudoreference electrodes. The cell and electrolyte were purged with argon prior to use. The Pt electrode was polished successively with 5,1 , and $0.01 \mu \mathrm{m}$ alumina slurries on lapping pads.

Both macro-scale and on chip determination of the chloride concentration by cyclic voltammetry (CV) as well as phenol passivation and cleaning experiments were recorded with a PC controlled potentiostat/galvanostat EG\&G Model 273A, using the EG\&G EChem software. All other experiments were recorded with a PC controlled Autolab $\mu$ AUTIII potentiostat, using Eco Chemie GPES 4.9.

Details of the Microfluidic Device. The apparatus for the automated sample preparation and delivery used Nemesys syringe drives (Cetoni) with $250 \mu \mathrm{L}$ Gastight syringes (Hamilton) to control flow through a network constructed from two glass chips supplied by Micronit Microfluidics and interconnecting capillary tubing and fittings (Upchurch). The maximum injection rate for each syringe within the system was $0.1 \mu \mathrm{L} \mathrm{s}^{-1}$ based upon specified pressure tolerances for the syringes. The first glass chip contained an 18 element tear-drop mixer ${ }^{32,33}$ supplied off the shelf (Micronit TD18), and the second chip was designed in house and included the electrochemical cell used in the experiments. Figure 1a shows a diagram of the flow network. The two syringes A and B supply the mixer to create a prescribed uniform mixture for the electrochemical cell. For example with syringe A filled with a known ferrocene and IL mixture and syringe $B$ with a pure IL, a ferrocene solution of concentration anywhere in the range from zero to that of the syringe A solution can be supplied to the electrochemical cell. The additional syringe, $\mathrm{C}$, is filled with an IL with high chloride concentration for use as an electrode cleaning agent. The volume flow rates from syringes A and B determine the concentration emerging from the mixer once steady conditions are reached and, again depending on the flow rates set, either flow from the mixer or from Syringe $C$ can be sent to the electrochemical cell. Thus, under computer control of the three syringes considerable flexibility in the sequence of flow is available. Figure $1 \mathrm{~b}$ shows the two chips clamped in holders facilitating the flow and electrical connections. The flow connections were made using Nanoport fittings and ferrules, PEEK

(32) Chen, Z.; Bown, M.; O’Sullivan, B.; MacInnes, J. M.; Allen, R. W. K.; Mulder, M.; Blom, M.; van’t Oever, R. Microfluid. Nanofluid. 2008, in press.

(33) Priestman, G. H.; MacInnes, J. M.; Tippetts, J. R.; Allen, R. W. K. Fluidic oscillators for measurement, mixing and monitoring in micro reactors. Proceedings of the 7th World Congress of Chemical Engineering, Glasgow, U.K., July 10-14, 2005. 
(a)

Syringes

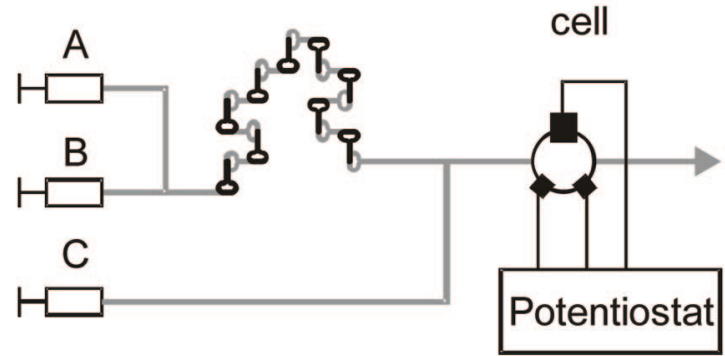

(b)

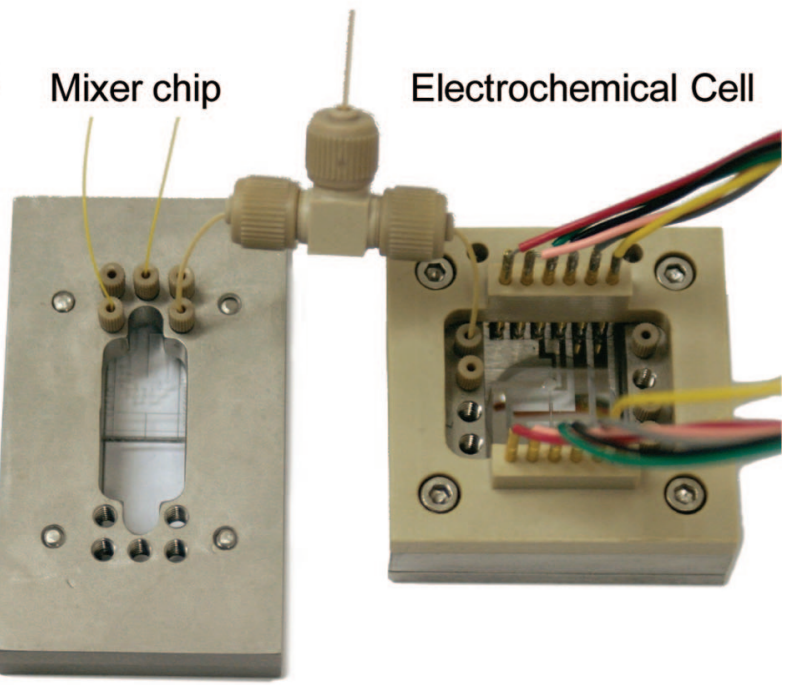

Figure 1. (a) Diagram of experimental apparatus. The two syringes $A$ and $B$ supply the mixer to form prescribed mixture to the electrochemical cell. Syringe $C$ is used in the experiments to supply high concentration chloride solution to the cell for cleaning. (b) Mixer chip and electrochemical cell arrangement showing the chip holders, capillary flow connections between the two chips and the "T" junction fitting. The three input streams come in from the top of the photograph (two into the mixer chip and one into the $T$ fitting). The outlet capillary from the electrochemical cell goes out the right-hand side of the photograph (not visible) and the electrical connection for the working, pseudo-reference, and counter electrodes are included in the wire bundles exiting to the right.

MicroTee fitting and $150 \mu \mathrm{m}$ internal diameter PEEK capillary tubing (Upchurch). Electrical connections were made using standard spring pins (RS). The mixer is expected to produce uniformity at is outlet of less than $0.1 \%$ standard deviation in composition relative to the average for the conditions of operation. ${ }^{34}$ The electrochemical cell cavity encloses $260 \mathrm{~nL}$ volume and is formed by wet etching $75 \mu \mathrm{m}$ into one glass layer and depositing a $100 \mathrm{~nm}$ thick platinum pattern on a second to form the cell electrodes and electrical connections. When the layers are bonded together the cell is completed, with etched passages $250 \mu \mathrm{m}$ wide (and $75 \mu \mathrm{m}$ deep) leading flow to and from the cell. The electrodes overlap the edges of the cell as indicated in Figure 1a such that the contact area with fluid in the cell is $0.0033 \mathrm{~cm}^{2}$ for the working electrode and $0.0015 \mathrm{~cm}^{2}$ each for the pseudoreference and counter electrodes. The holes leading from the chip channel passages up to the capillary connections in both the mixer and the electrochemical chips are powder-blasted, and these holes have volumes 1.1 and $0.3 \mu \mathrm{L}$, respectively.

(34) MacInnes, J. M.; Vikhansky, A.; Allen, R. W. K. Chem. Eng. Sci. 2007, 62, 2718-2727.
When switching from one stream or mixture to the next it is necessary to clear out the existing solution so the desired composition is present in pure form in the electrochemical cell. Achieving this requires passing a sufficient volume along the path leading from the point of introduction of the new solution (the junction leading into the mixer in this case) through to the outlet of the cell. The larger this path volume, the more solution volume must flow to produce a given level of purity. Thus, the internal volume (capillary tubing and chip passages including connection holes, channels, and the electrochemical cell itself) between the mixer junction and cell outlet is an important parameter. This path volume is estimated to be $3.8 \mu \mathrm{L}$.

Two things are crucial to ensure pure deposition in the cell can be achieved. First, unused streams must be retracted from the junctions through which the desired solution flows. Otherwise diffusion of material from the unused streams into the stream that is being deposited will mean contamination of the solution used to flush the path volume. While eventually the unused streams at a junction will be cleared by the diffusion this will take an impractically long time and large amount of sample solution to achieve good sample purity in the cell. Efficient clearing, therefore, requires an initial rapid retraction of all unused streams back away from the junctions so the desired solution may pass uncontaminated.

Second, when the syringe drives are stopped mechanical relaxation occurs (in the drive mechanism, syringes, and liquid) which produces a brief continuation of flow from all syringes. The materials associated with this flow has an uncontrolled composition and must not reach the electrochemical cell. It may be possible to compensate to a large degree for the relaxation by retraction of the syringes to minimize the leaked solution volume. Herein, the experiments were conducted such that the path volume between junction and electrochemical cell was sufficiently large for the uncontrolled mixture not to reach the cell. For the flow rates, and hence pressure changes, used in the experiments the relaxation flow is estimated to expel up to $100 \mathrm{~nL}$ from each syringe supply. Thus up to a total of $300 \mathrm{~nL}$ may leak from the three solutions. Approximately twice that volume of the passage may be affected since the core of the flow travels further than the average (by exactly twice in a capillary passage, see, e.g., ref 35 ). With the downstream passage volume being $1 \mu \mathrm{L}$ for the $\mathrm{T}$ junction and $3.5 \mu \mathrm{L}$ for the mixer junction, the electrochemical measurement cell should be protected from the uncontrolled mixture produced during relaxation.

\section{RESULTS AND DISCUSSION}

Validation of the Injection Protocol and Mixer Chip to Accurately Prepare Known Mixtures. Although the effectiveness of the low Reynolds number mixer chip has previously been demonstrated, ${ }^{33,34,36}$ the combination of an automated injection system plus mixer chip (Figure 1a,b) had not been validated to produce known concentrations of samples inside a subsequent chip. The protocol used was, therefore, tested using ferrocene (Fc) solutions measured using UV-vis absorption spectroscopy. A concentrated sample of ferrocene (50 mM, ca. $15000 \mathrm{ppm})$ was prepared in methanol $(\mathrm{MeOH})$ and loaded into syringe $\mathrm{A}$, while

(35) MacInnes, J. M.; Du, X.; Allen, R. W. K. Phys. Fluids 2003, 15, 1992-2005.

(36) MacInnes, J. M.; Chen, Z.; Allen, R. W. K. Chem. Eng. Sci. 2005, 60, 34533467.

Analytical Chemistry, Vol. 81, No. 4, February 15, 2009

1631 


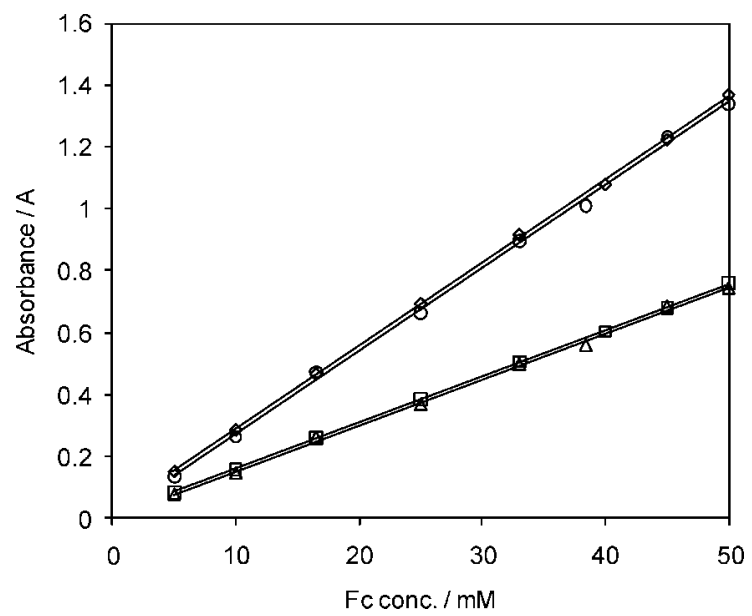

Figure 2. Comparison of the UV-vis absorbance of solutions of ferrocene prepared on-chip $\left(440 \mathrm{~nm}(O)\left(R^{2}=0.998\right)\right.$ and $325 \mathrm{~nm}$ $\left.(\triangle)\left(R^{2}=0.997\right)\right)$ and off-chip $\left(440 \mathrm{~nm}(\diamond)\left(R^{2}=0.999\right)\right.$ and $325 \mathrm{~nm}$ ( $\left.\square)\left(R^{2}=0.999\right)\right)$, as a function of the ferrocene concentration. The concentrations were set using the control program and made by mixing a Fc solution (50 mM Fc in methanol) with pure methanol within the mixer chip.

pure $\mathrm{MeOH}$ was loaded into syringe $\mathrm{B}$. Consecutively, eight mixing ratios were then used to prepare $1000 \mu \mathrm{L}$ samples for off chip analysis, after passing through the entire system, and after discarding the first ca. $100 \mu \mathrm{L}$.

Figure 2 compares the UV-vis absorption as a function of concentration prepared on chip, as well as off chip, using micropipettes. Ferrocene is known to possess two absorption peaks in methanol, corresponding to 325 and $440 \mathrm{~nm},{ }^{37}$ and both methods gave consistent data with linear plots of excellent fit demonstrating the reliability of the mixing and injection methodology under steady flow conditions.

ILs have a much higher viscosity, in general, than molecular solvent and therefore the mixing of ILs was validated within the microfluidic device using stop-flow and the electrochemistry cell. Eleven samples were prepared by mixing a $50 \mathrm{mM}$ solution of ferrocene in $\left[\mathrm{C}_{4} \mathrm{mim}\right]\left[\mathrm{NTf}_{2}\right]$ in syringe $\mathrm{A}$ with pure $\left[\mathrm{C}_{4} \mathrm{mim}\right]\left[\mathrm{NTf}_{2}\right]$ in syringe $\mathrm{B}$, and the concentrations measured using $\mathrm{CV}$.

Figure 3 displays the correlation between both the peak area and the peak current of the $\mathrm{Fc}$ oxidation peak versus the $\mathrm{Fc}$ concentration expected from the mixing chip. In both cases a good linear fit between $0-50 \mathrm{mM}$ was obtained demonstrating that efficient and predictable mixing was achievable with the high viscosity media. Figure 4 shows the effect of scan rate on the peak area and peak current using a $50 \mathrm{mM}$ solution of $\mathrm{Fc}$ in $\left[\mathrm{C}_{4} \mathrm{mim}\right]\left[\mathrm{NTf}_{2}\right]$ over 5 to $300 \mathrm{mV} \mathrm{s}^{-1}$. In each case an ideal linear response was observed.

By increasing mass transfer, the size of the current response at the electrode can be increased. As such, steady-state voltammetry is a desirable technique for low concentrations of analyte. $\mathrm{CVs}$ were carried out for injection ratios for syringe A containing $50 \mathrm{mM}$ solution of ferrocene in $\left[\mathrm{C}_{4} \mathrm{mim}\right]\left[\mathrm{NTf}_{2}\right]$ : syringe $\mathrm{B}$ containing pure $\left[\mathrm{C}_{4} \mathrm{mim}\right]\left[\mathrm{NTf}_{2}\right]$ of $1: 0,0.3: 0.7$, and $0.1: 0.9$

(37) Lagunas, M. C.; Pitner, W. R.; van den Berg, J. A.; Seddon, K. R. ACS Symp. Ser. 2003, 856, 421-438; Ionic Liquids As Green Solvents: Progress And Prospects.

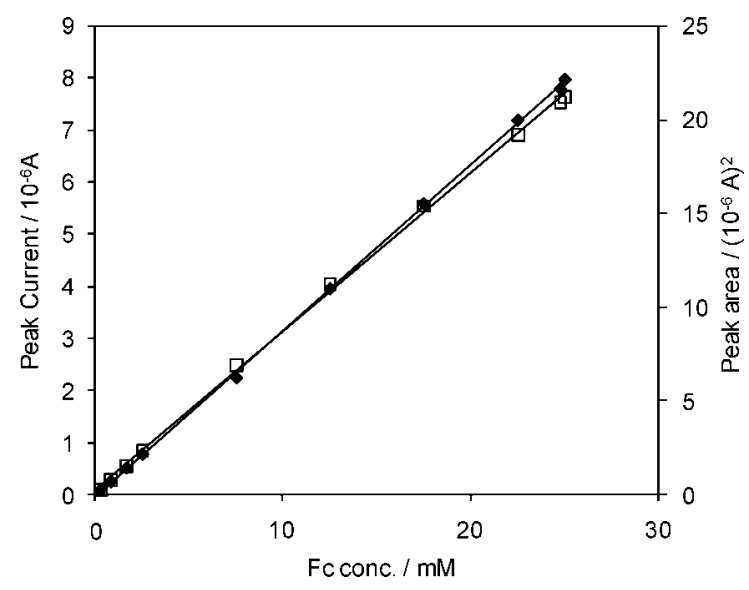

Figure 3. Calibration plots for the $\mathrm{CV}$ of Fc solutions, generated by mixing various volume ratios of a $50 \mathrm{mM}$ solution of $\mathrm{Fc}$ in $\left[\mathrm{C}_{4}\right.$ mim] $\left[\mathrm{NTf}_{2}\right]$ with pure $\left[\mathrm{C}_{4}\right.$ mim] $\left[\mathrm{NTf}_{2}\right]$ within the mixer chip, displaying peak area vs predicted $\mathrm{Fc}$ concentration $\left(\diamond, R^{2}=0.999\right)$ and peak current vs predicted Fc concentration $\left(\square, R^{2}=0.999\right)$.
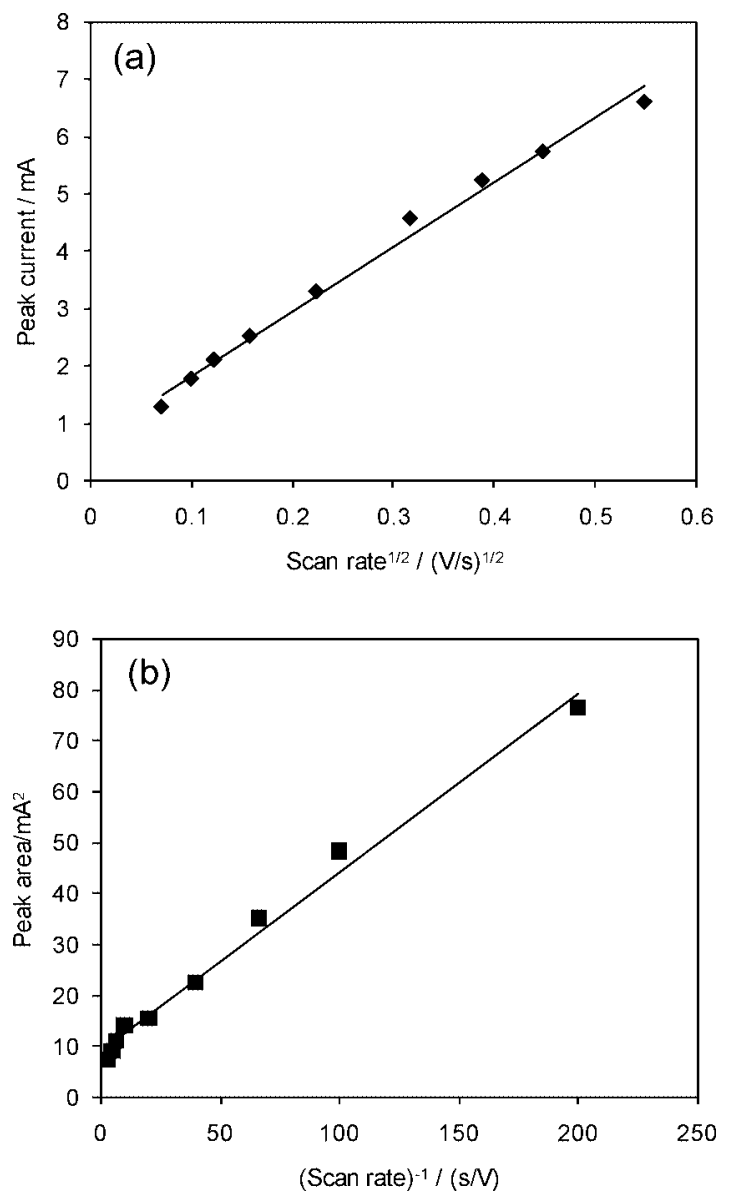

Figure 4. Plots for a $50 \mathrm{mM}$ solution of $\mathrm{Fc}$ in $\left[\mathrm{C}_{4} \mathrm{mim}\right]\left[\mathrm{NTf}_{2}\right]$, displaying (a) peak current vs the square root of the scan rate $\left(R^{2}=\right.$ $0.992)$ and (b) peak area vs the inverse of the scan rate $\left(R^{2}=0.989\right)$.

(Figure 5a). Under all conditions used, steady state current response was observed with a linear current response with $\mathrm{Fc}$ concentration. Therefore, steady state voltammetry can be carried out using this apparatus, including automated mixing of sample, while only consuming IL on the $\mu \mathrm{L}$-scale. Figure $5 \mathrm{~b}$ also includes the peak current values and peak area values for the three injection 

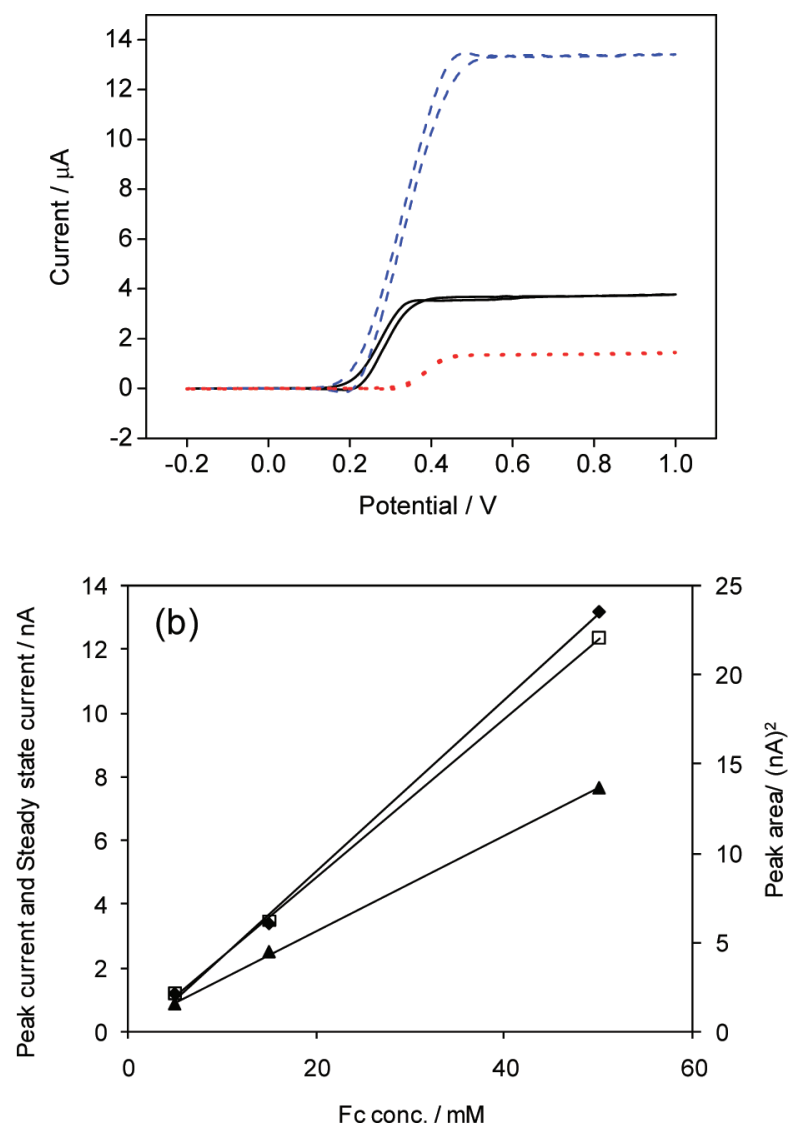

Figure 5. (a) "Steady-state" voltammetry at different injection ratios (total flow rate $1 \mu \mathrm{L} / \mathrm{s}$ ) giving Fc concentrations of $50 \mathrm{mM} \mathrm{Fc}$ (dashed line), $15 \mathrm{mM} \mathrm{Fc}$ (solid line) and $5 \mathrm{mM} \mathrm{Fc}$ (dotted line) in [ $\left.\mathrm{C}_{4} \mathrm{mim}\right]\left[\mathrm{NTf}_{2}\right]$. (b) Comparison plots for "steady-state" peak current $\left(\bullet, R^{2}=0.998\right)$, quiescent state peak currents $\left(\boldsymbol{\Lambda}, R^{2}=0.999\right)$ and quiescent state peak areas $\left(\square, R^{2}=0.999\right)$ at each Fc concentration.

ratios when scanned under quiescent conditions. From the definition that sensitivity is the current response divided by concentration, it is observed that peak area is still a more sensitive means of concentration determination than peak current. However, steady-state voltammetry offers an improvement over quiescent peak current measurement.

Electrochemical Quantification of Halide Content by CV: Comparison between Microfluidic Device and Conventional Macro-Electrode Setup. Villagrán et al. reported that linear sweep voltammetry at a glassy carbon (GC) macro-electrode can be used to quantify chloride content in ILs using chloride oxidation with a limit of quantification at the parts per million level. ${ }^{24}$ For example, a limit of quantification of $4.2 \mathrm{ppm}$ was found for $\left[\mathrm{C}_{4} \mathrm{mim}\right]\left[\mathrm{NTf}_{2}\right]$ using this methodology. This procedure was repeated in an electrochemical cell using a Pt macro-scale working electrode and two Pt wires as counter and quasireference electrodes to mirror the setup in the microfluidic electrochemical cell. Ten solutions of $\left[\mathrm{C}_{4} \mathrm{mim}\right]\left[\mathrm{NTf}_{2}\right]$ with chloride contents between $49 \mathrm{ppm}$ to $1400 \mathrm{ppm}$ were prepared by adding chloride in the form of $\left[\mathrm{C}_{4} \mathrm{mim}\right] \mathrm{Cl}$. The voltammetry observed was consistent with that previously reported for $\left[\mathrm{C}_{4} \mathrm{mim}\right] \mathrm{Cl}$ at $\mathrm{Pt}$ in $\left[\mathrm{C}_{4} \mathrm{mim}\right]\left[\mathrm{NTf}_{2}\right] .^{38}$ Linear correlations were observed between peak current and chloride content at scan

(38) Aldous, L.; Silvester, D. S.; Villagrán, C.; Pitner, W. R.; Compton, R. G.; Lagunas, M. C.; Hardacre, C. New J. Chem. 2006, 30, 1576-1583. rates of both $5 \mathrm{mV} \mathrm{s}^{-1}$ and $100 \mathrm{mV} \mathrm{s}^{-1}$ (Figure 6). The scans at $5 \mathrm{mV} \mathrm{s}^{-1}$ were observed to be more reproducible but took approximately $260 \mathrm{~s}$ to complete, while scans at $100 \mathrm{mV} \mathrm{s}^{-1}$ took about $13 \mathrm{~s}$ and gave greater current response but poorer signal-to-noise ratios at lower $\mathrm{Cl}^{-}$concentrations, that is, at 100 $\mathrm{mV} \mathrm{s}^{-1}$.

The same solutions were also analyzed by linear sweep voltammetry on chip. It should be noted that for these experiments a single syringe and syringe pump was used, and the mixer chip was bypassed. A strong correlation between current and chloride content was also observed over all concentrations on the microfluidic device. Panels $\mathrm{b}$ and $\mathrm{d}$ of Figure 6 display the linear sweep scans for all chloride contents at $100 \mathrm{mV} \mathrm{s}^{-1}$ and the correlation between peak current at $5 \mathrm{mV} \mathrm{s}^{-1}$ and $100 \mathrm{mV} \mathrm{s}^{-1}$ with added chloride content, respectively. The improvement in the linear correlation upon moving from the macro- to the microscale setup is attributed to the fixed position of the electrodes within the cell. In the macro-electrode more variability of the distances between the working, counter, and reference electrodes is possible and, therefore, the microfluidic device presents a clear improvement for repeated analytical work. In addition, the macro-electrode experiments typically used at least $15000 \mu \mathrm{L}$ for a ten-point calibration with $\left[\mathrm{C}_{4} \mathrm{mim}\right]\left[\mathrm{NTf}_{2}\right]$, compared with about $1000 \mu \mathrm{L}$ (sample + chloride-spiked sample) on the microfluidic device showing the benefit of moving to the small scale.

Flushing of the Microfluidic Device. To investigate a large number of samples while minimizing the volume used, it is necessary to be able to flush out the preceding sample with the next sample. To evaluate the efficiency in flushing out the old sample, the number of volume changes required to completely remove a sample from the electrochemical cell was examined. Volume changes were delivered incrementally, six path volume changes at a time, with the flow stopped between increments to allow a CV scan to be made. While this is not ideal since mechanical relaxation causes the retracted unused streams to flow into the path volume, it was a convenient way to collect data. Three concentration samples of $\mathrm{Fc}$ solution in $\left[\mathrm{C}_{4} \mathrm{mim}\right]\left[\mathrm{NTf}_{2}\right], 66 \mathrm{mM}$ ( $\sim 12500 \mathrm{ppm}), 26.4 \mathrm{mM}$ ( $\sim 5000 \mathrm{ppm})$, and $6.6 \mathrm{mM}(\sim 1250$ $\mathrm{ppm})$, were introduced into the cell, and $\mathrm{CV}$ was used to measure the concentration of $\mathrm{Fc}$ as a function of the number of path volume changes of pure $\left[\mathrm{C}_{4} \mathrm{mim}\right]\left[\mathrm{NTf}_{2}\right]$ injected as the washing solvent. Although a significant drop is observed, beyond 12 volume changes the Fc concentration appears to have reached a plateau value dependent on initial concentration as can be seen by plotting the data on semilog axes, Figure 7 . The decay in contamination concentration is expected to be more rapid than exponential for this convection-diffusion process while the plateau tendency of the results shows a far slower than exponential decay. The likely cause is the incremental delivery which, because of the relaxation effect, allows deposition of some Fc solution into the path volume downstream of the mixer inlet junction following each increment.

Electrode Fouling and Regeneration Techniques. Because of the fixed nature of the electrochemical cell within the microfluidic device, it is not possible to clean the electrodes by mechanical means and, therefore, chemical cleaning is necessary. To investigate the efficiency of such cleaning, the electrodes were 

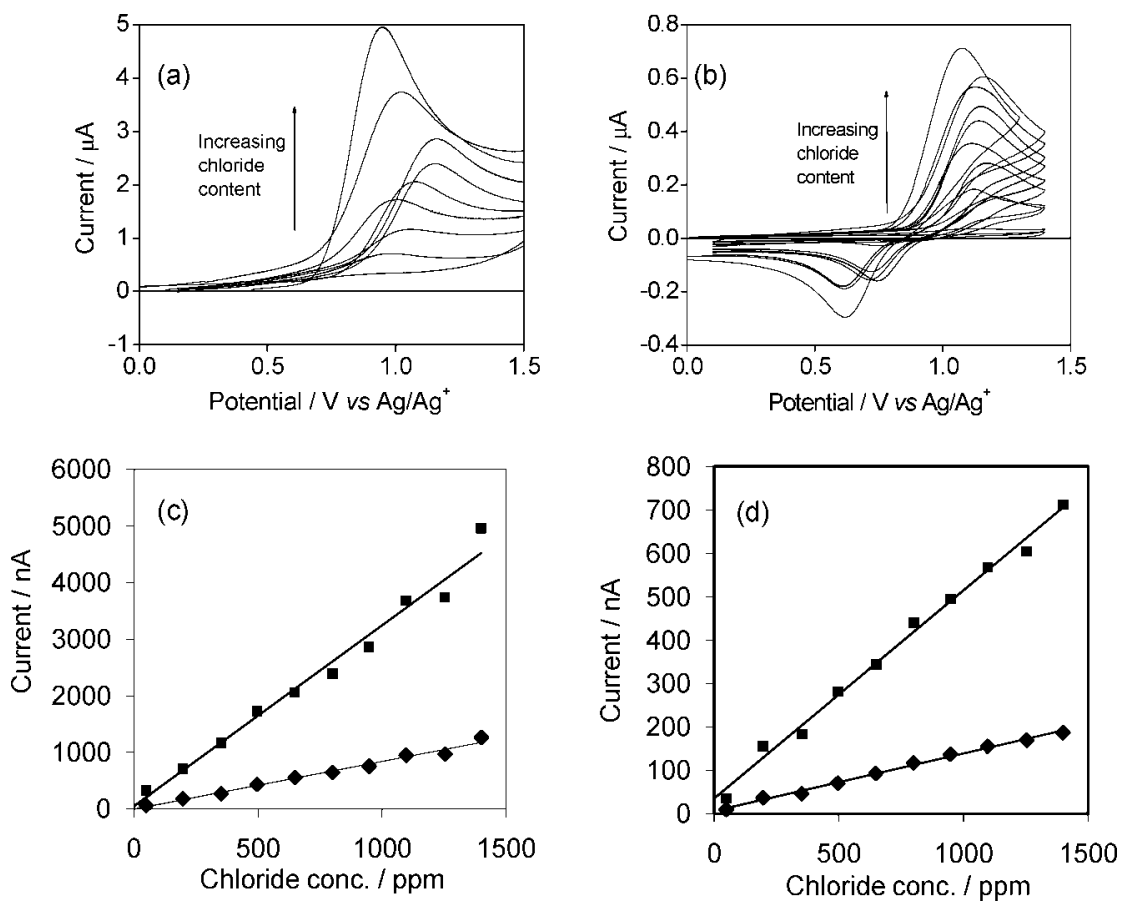

Figure 6. Linear sweep and $\mathrm{CV}$ of various chloride concentrations in $\left[\mathrm{C}_{4}\right.$ mim] $\left[\mathrm{NTf}_{2}\right]$ using (a) a macro-electrode setup and (b) the microfluidic device. A comparison of peak current using (c) a macro-electrode setup at $5 \mathrm{mV} \mathrm{s}^{-1}\left(\boldsymbol{\square}, \mathrm{R}^{2}=0.985\right)$ and $100 \mathrm{mV} \mathrm{s^{-1 }}\left(\bullet, \mathrm{R}^{2}=0.978\right)$ and $(\mathrm{d})$ the microfludic device at $5 \mathrm{mV} \mathrm{s}^{-1}\left(\mathbf{\square}, \mathrm{R}^{2}=0.994\right)$ and $100 \mathrm{mV} \mathrm{s}^{-1}\left(\bullet, \mathrm{R}^{2}=0.992\right)$.

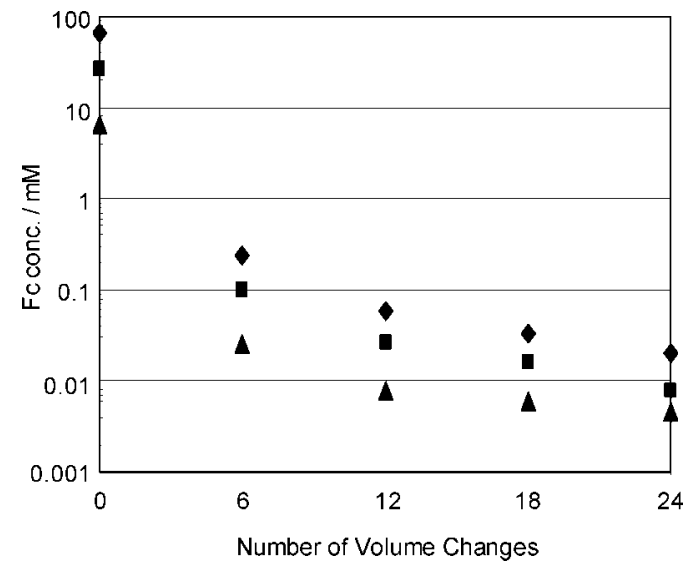

Figure 7. Concentration of Fc remaining in the chip after flushing various concentrations $(66 \mathrm{mM}(\bullet), 24.6(\boldsymbol{\square})$, and $6.6 \mathrm{mM}(\boldsymbol{\Delta}))$ of $\mathrm{Fc}$ in $\left[\mathrm{C}_{4} \mathrm{mim}\right]\left[\mathrm{NTf}_{2}\right]$ with $6,12,18$ and 24 volume changes of pure $\left[\mathrm{C}_{4} \mathrm{mim}\right]\left[\mathrm{NTf}_{2}\right]$, based upon peak oxidation current.

deliberately passivated using phenol oxidation and polymerization. $^{39}$ Recently, Villagrán et al. demonstrated that in $\left[\mathrm{C}_{2}\right.$ mim $]\left[\mathrm{NTf}_{2}\right]$ using a GC electrode, phenol displays a single oxidation peak, and bulk oxidation leads to the formation of polymerization product. ${ }^{39}$ After injecting a $15 \mathrm{mM}$ solution of phenol in $\left[\mathrm{C}_{4} \mathrm{mim}\right]\left[\mathrm{NTf}_{2}\right]$, three consecutive $\mathrm{CVs}$ showed initially a large oxidation peak at about $+1.75 \mathrm{~V}$ versus $\mathrm{Pt}$ followed by no clear oxidation peaks in the second and third scans (Figure 8a). Similarly, on injecting a $15 \mathrm{mM}$ solution of ferrocene in $\left[\mathrm{C}_{4} \mathrm{mim}\right]\left[\mathrm{NTf}_{2}\right]$ after passivation, no significant oxidation features were observed (Figure $8 \mathrm{~b}$ ). The fact that the passivation was not removed after flushing indicates that the electrode surface was fouled by a strongly adsorbed layer.

(39) Villagrán, C.; Aldous, L.; Lagunas, M. C.; Compton, R. G.; Hardacre, C. J. Electroanal. Chem. 2006, 588, 27-31.
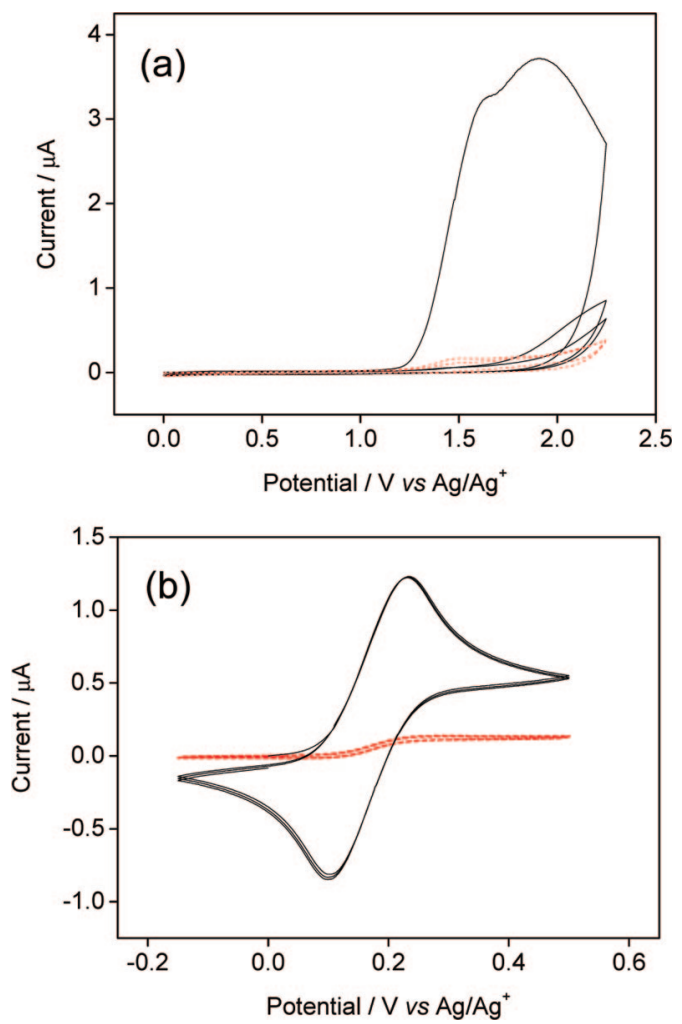

Figure 8. (a) CV of a $15 \mathrm{mM}$ solution of phenol in $\left[\mathrm{C}_{4} \mathrm{mim}\right]\left[\mathrm{NTf}_{2}\right]$, displaying the first three consecutive scans (solid line) and three more consecutive scans after injecting $10 \mu \mathrm{L}$ fresh phenol solution (dashed line). (b) Overlay of ferrocene scans before (solid line) and after (dashed line) electrode passivation by phenol oxidation.

Alternating the polarity of platinum electrodes has the potential to desorb some adsorbed compounds, especially charged compounds. ${ }^{26}$ Cleaning of this type was evaluated by rapidly scanning 

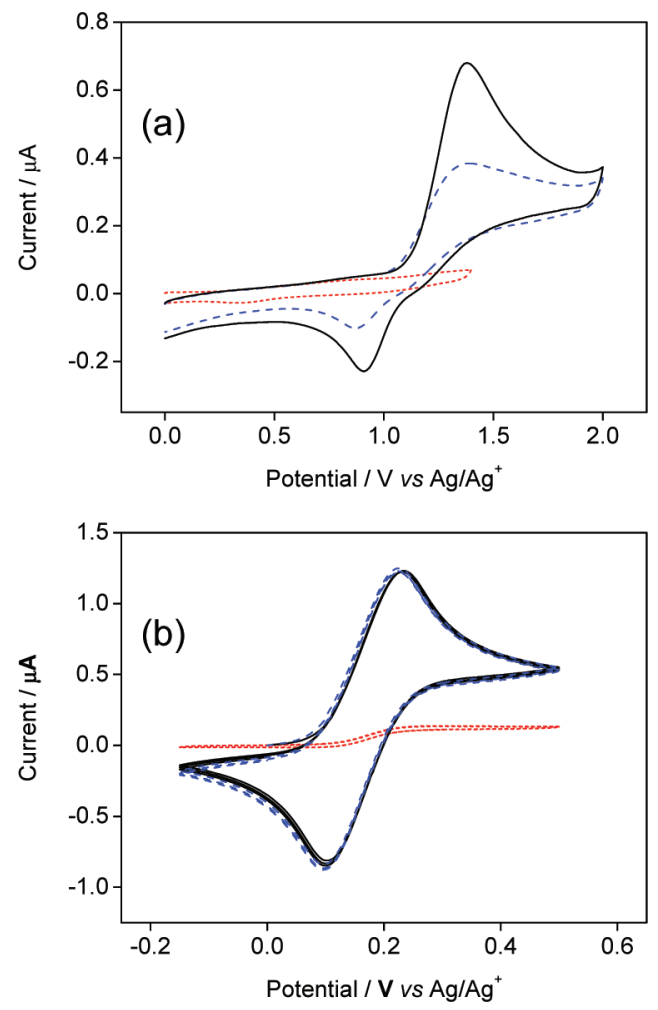

Figure 9. (a) $\mathrm{CV}$ of a $15 \mathrm{mM}$ solution of $\left[\mathrm{C}_{4} \mathrm{mim}\right] \mathrm{Cl}$ in $\left[\mathrm{C}_{4} \mathrm{mim}\right]\left[\mathrm{NTf}_{2}\right]$, after phenol passivation but prior to cleaning (dotted line), after being partially cleaned (dashed line) and after being completely cleaned (solid line). (b) CV of a $15 \mathrm{mM}$ solution of $\mathrm{Fc}$ in $\left[\mathrm{C}_{4} \mathrm{mim}\right]\left[\mathrm{NTf}_{2}\right]$ prior to phenol passivation (solid line), after phenol passivation (dotted line), and after electrode cleaning (dashed line).

between +0.5 and $-0.5 \mathrm{~V}$, holding at each vertex for $3 \mathrm{~s}$, while flowing pure $\left[\mathrm{C}_{4} \mathrm{mim}\right]\left[\mathrm{NTf}_{2}\right]$ at $5 \mu \mathrm{L} \mathrm{min}^{-1}$. However, a quiescent scan of a $15 \mathrm{mM}$ solution of ferrocene in $\left[\mathrm{C}_{4} \mathrm{mim}\right]\left[\mathrm{NTf}_{2}\right]$ before and after cleaning showed only a marginal improvement in the response. In contrast, chemical cleaning via the generation of gas bubbles and a reactive chemical species, in this case chlorine, showed significant improvement. An $11.5 \mathrm{mM}$ solution of $\left[\mathrm{C}_{4} \mathrm{mim}\right] \mathrm{Cl}$ in $\left[\mathrm{C}_{4} \mathrm{mim}\right]\left[\mathrm{NTf}_{2}\right]$ was introduced into the cell and the potential held at $+2 \mathrm{~V}$ for $60 \mathrm{~s}$, to generate $\mathrm{Cl}_{2}$. Prior to this treatment, no chloride oxidation was observed because of the phenolic passivation; however, following sustained oxidation of the chloride to chlorine, scans of the chloride solution demonstrated gradually increasing oxidation peaks, reaching half the expected size after 7 treatments and producing chloride oxidation peaks consistent with that observed prior to phenol oxidation after 12 treatments (Figure 9). Careful control of the potential was also required as electrolysis at potentials of $\geq+2.2 \mathrm{~V}$, that is, beyond the oxidative window of $\left[\mathrm{C}_{4} \mathrm{mim}\right]\left[\mathrm{NTf}_{2}\right]$, was found to result in an overall decrease in the chloride oxidation peak because of passivation by oxidative decomposition of the IL, an effect that was only reversed by further chlorine generation at $+2 \mathrm{~V}$. Figure 9 indicates the effect of cleaning the electrode by showing $\mathrm{CV}$ scans of ferrocene at various stages of cleaning.

Optimization of Electrode Regeneration. On measuring the chloride content in the ILs using the microfluidic device, at high chloride concentrations there was sufficient generation of $\mathrm{Cl}_{2}$ to clean the electrodes resulting in excellent reproducibility between samples. Therefore, no secondary cleaning was necessary. However, at lower chloride concentrations, typically below values of $40 \mathrm{ppm}$, the reproducibility decreased and additional surface regeneration in the form of $\mathrm{Cl}_{2}$ generation was required. To produce sufficiently clean electrodes, a minimum chloride concentration of $400 \mathrm{ppm}$ was required with the time taken for the treatment dependent on the concentration and the IL used. In general, it was found that four $15 \mathrm{~min}$ $\mathrm{Cl}_{2}$ pretreatments generated using a $400 \mathrm{ppm} \mathrm{Cl}^{-}$solution with flushing the chip with a fresh $400 \mathrm{ppm}$ solution between each treatment was adequate to give reproducible results. This was achieved using a single syringe operation filled with the 400 ppm $\mathrm{Cl}^{-}$IL solution.

While a 60 min long pretreatment step between samples using $400 \mathrm{ppm}$ chloride solutions proved excellent for small batches of samples, the time required for the cleaning significantly reduced the turnover of samples possible. Much shorter treatment times were possible by increasing the concentration of chloride in $\left[\mathrm{C}_{4} \mathrm{mim}\right]\left[\mathrm{NTf}_{2}\right]$. Following fouling of the electrodes, the oxidative peak current of $40 \mathrm{ppm}$ chloride was measured to probe electrode cleanliness. Using a 5 min treatment with either 2000 and $4000 \mathrm{ppm}$ chloride did not result in reproducible oxidation currents (vs the established 60 min cleaning with $400 \mathrm{ppm} \mathrm{Cl}^{-}$), indicating that a consistent electrode surface was not being achieved. In contrast, chlorine generation for 5 min using a $8000 \mathrm{ppm}$ chloride solution resulted in a peak area within $\sim 25 \%$ of that observed after the 60 min cleaning method. Furthermore, extending the cleaning time to $10 \mathrm{~min}$ resulted in a peak area $\sim 5 \%$ of the ideal value. It should be noted that, although the cleaning protocol can be significantly speeded up by the use of solutions containing higher chloride content, more IL is used in flushing the chloride solution from the electrochemical cell to reach acceptable purity prior to analysis of the next sample.

Quantification of Chloride Using Square Wave (SWV) and Differential Pulse (DPV) Voltammetry. While both square wave (SWV) and differential pulse (DPV) gradually scan through ranges of potentials in a manner similar to linear sweep voltammetry, both techniques also subtract background current. This typically leads to improved signal-to-noise ratios and results in more sensitive and reproducible data. This was demonstrated in the quantification of halide in ILs by Villagrán et al. Therein, while LSV and SWV measurements of chloride content in $\left[\mathrm{C}_{4} \mathrm{mim}\right]\left[\mathrm{NTf}_{2}\right]$ gave limits of detection (LOD) of 4.2 and 4.3 ppm, respectively, SWV gave a significantly lower limit of quantification (LOQ) of $6.8 \mathrm{ppm}$ relative to $25.6 \mathrm{ppm}$ from linear sweep voltammetry. ${ }^{39}$

Halide contents between 5 and $40 \mathrm{ppm}$ were investigated using SWV and DPV in $\left[\mathrm{C}_{4} \mathrm{mim}\right]\left[\mathrm{NTf}_{2}\right],\left[\mathrm{C}_{4} \mathrm{mim}\right][\mathrm{OTf}],\left[\mathrm{C}_{4} \mathrm{mim}\right]\left[\mathrm{BF}_{4}\right]$, [C $\left.\mathrm{C}_{4} \mathrm{mPyrr}\right]\left[\mathrm{NTf}_{2}\right],\left[\mathrm{P}_{666,14}\right]\left[\mathrm{NTf}_{2}\right]$, and $\left[\mathrm{C}_{4} \mathrm{mPyrr}\right][\mathrm{FAP}]$. A standard procedure was followed, whereby syringe A was loaded with a solution of $40 \mathrm{ppm}$ of the chloride salt of the IL cation dissolved in the target IL, while syringe B was loaded with the pure IL. Syringe C was loaded with a 400 ppm "cleaning" solution of the chloride salt dissolved in the IL to be measured. Samples were then mixed at various concentrations using the automated mixer, and scans recorded using SWV and DPV, with 60 min cleaning (by $\mathrm{Cl}_{2}$ generation) performed between 


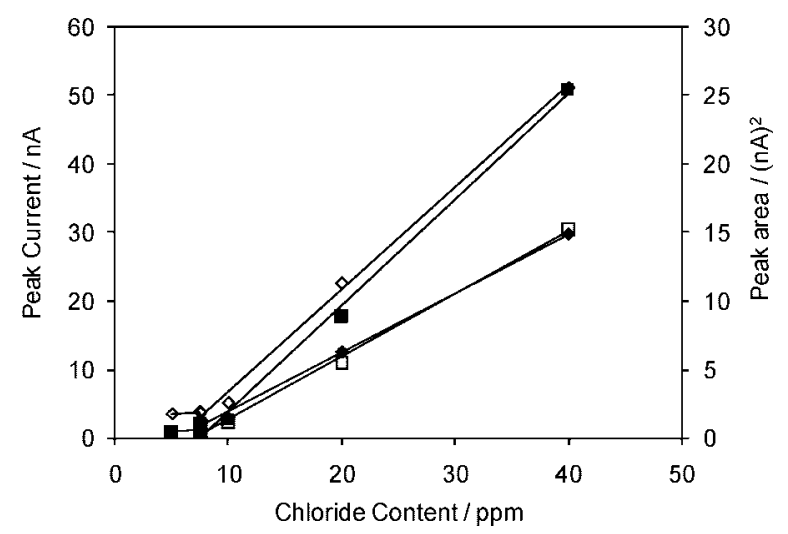

Figure 10. Comparison of the peak area and peak current as a function of chloride concentration at different frequencies, showing peak area at $32 \mathrm{~Hz}\left(\diamond, R^{2}=0.997\right)$ and $8 \mathrm{~Hz}\left(\diamond, R^{2}=0.999\right)$ and peak current at $32 \mathrm{~Hz}\left(\square, R^{2}=0.999\right)$ and $8 \mathrm{~Hz}\left(\square, R^{2}=0.999\right)$ for chloride in $\left[\mathrm{C}_{4} \mathrm{mim}\right]\left[\mathrm{NTf}_{2}\right]$.
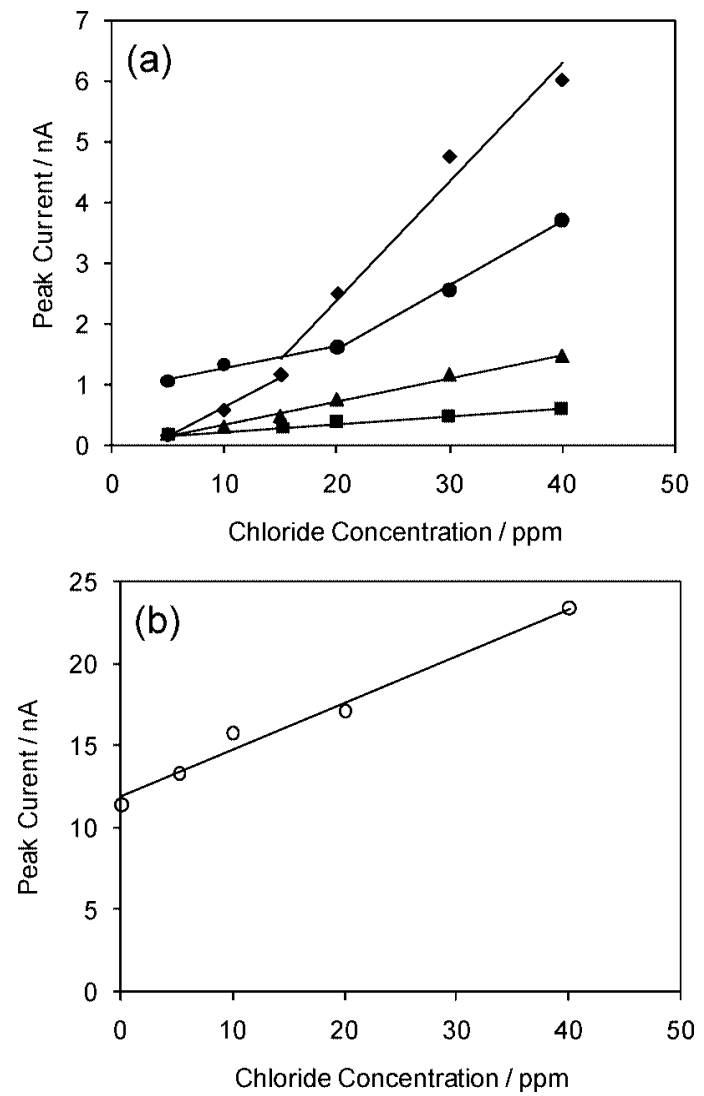

Figure 11. DPV peak current as a function of chloride concentration, for (a) $\left[\mathrm{C}_{4}\right.$ mim] [OTf] $\left(\diamond, R^{2}=0.977\right),\left[\mathrm{C}_{4} \mathrm{mim}\right]\left[\mathrm{BF}_{4}\right]\left(\bullet, R^{2}=0.999\right)$, $\left[\mathrm{C}_{4} \mathrm{mPyrr}_{[}\left[\mathrm{NTf}_{2}\right]\left(\boldsymbol{\Lambda}, R^{2}=0.992\right),\left[\mathrm{P}_{666,14}\right]\left[\mathrm{NTf}_{2}\right]\right.$ diluted with 20 wt \% acetonitrile $\left(\mathbf{\square}, R^{2}=0.991\right)$ and $(\mathrm{b})\left[\mathrm{C}_{4} \mathrm{mPyrr}\right][\mathrm{FAP}]\left(\mathrm{O}, R^{2}=0.981\right)$.

the different scans/samples. In the case of $\left[\mathrm{P}_{666,14}\right]\left[\mathrm{NTf}_{2}\right]$, it was dissolved in acetonitrile at a weight ratio of 4:1 IL/ acetontrile to decrease the viscosity of the IL and thus improve the peak current with respect to the background current. In the case of $\left[\mathrm{C}_{4} \mathrm{mPyrr}\right][\mathrm{FAP}]$, an $8000 \mathrm{ppm}$ chloride cleaning solution was used over $10 \mathrm{~min}$.

Figure 10 and Figure 11 show the peak current and peak area dependencies with respect to the concentration of added chloride in the six ILs tested. Using the criteria of signal-to-noise ratio as
Table 2. LOD and LOQ for Chloride Determined for a Range of ILs Using SWV and DPV

\begin{tabular}{|c|c|c|c|}
\hline method & IL & LOD/ppm & $\mathrm{LOQ} / \mathrm{ppm}$ \\
\hline \multirow[t]{2}{*}{ SWV } & {$\left[\mathrm{C}_{4} \mathrm{mim}\right]\left[\mathrm{NTf}_{2}\right]$} & 5.7 & 7.3 \\
\hline & {$\left[\mathrm{C}_{4} \mathrm{mim}\right]\left[\mathrm{BF}_{4}\right]$} & 3.6 & 5.6 \\
\hline \multirow[t]{5}{*}{ DPV } & {$\left[\mathrm{C}_{4} \mathrm{mPyrr}\right]\left[\mathrm{NTf}_{2}\right]$} & 6.2 & 8.9 \\
\hline & {$\left[\mathrm{C}_{4} \mathrm{mPyrr}\right][\mathrm{FAP}]$} & 5.2 & 5.7 \\
\hline & {$\left[\mathrm{C}_{4} \mathrm{mim}\right][\mathrm{OTf}]$} & 5.0 & 5.2 \\
\hline & {$\left[\mathrm{C}_{4} \mathrm{mim}\right]\left[\mathrm{BF}_{4}\right]$} & 5.2 & 5.5 \\
\hline & {$\left[\mathrm{P}_{666,14}\right]\left[\mathrm{NTf}_{2}\right]^{a}$} & 8.5 & 16.7 \\
\hline
\end{tabular}

limit of detection (LOD) ${ }^{40}$ and the lowest value in the linear region as the limit of quantification (LOQ), the LOD and LOQ of each IL using SWV and DPV were determined and are summarized in Table 2. The LOD and LOQ of the present technique were found to be unexpectedly low considering the small size of the electrodes and the small amount of sample used. With the exception of the tetraalkyl phosphonium based IL with LOQ values of $<10 \mathrm{ppm}$, values observed were comparable to those found using the macroscale electrochemical cell. ${ }^{39}$ For $\left[\mathrm{P}_{666,14}\right]\left[\mathrm{NTf}_{2}\right]$ higher LOQ/LOD values were observed, as expected, because of the higher viscosity and concomitantly smaller signal.

Benefit of the Technique. Table 1 summarizes the limitations associated with a range of halide detection techniques used in IL analysis. Both the Volhard and spectrophotometric techniques suffer from extremely high LOQ values, while also contaminating the sample with the necessary reagents. Although ion chromatography is a versatile technique for analyzing halide content in ILs, the sample commonly must be diluted with water or a combination of water and a water miscible solvent. This can result in problems where the IL does not dissolve to a sufficient extent, for example, $\left[\mathrm{P}_{666,14}\right]\left[\mathrm{NTf}_{2}\right]$ or $\left[\mathrm{C}_{4} \mathrm{mPyrr}\right][\mathrm{FAP}]$, or where the IL may decompose on dissolution. Villagrán et al. highlighted that $\left[\mathrm{C}_{4} \mathrm{mim}\right]\left[\mathrm{BF}_{4}\right]$, when dissolved in a $\mathrm{H}_{2} \mathrm{O}$ /acetonitrile mixture, decomposes rapidly with the generation of fluorine observed by IC. ${ }^{17}$ In addition, for highly polarizable anions such as $\left[\mathrm{NTf}_{2}\right]^{-}$or $\left[\mathrm{PF}_{6}\right]^{-}$, extended sample runs are required to elute the IL anion even using a gradient elution system with high concentrations of base. ${ }^{17}$ Capillary zone electrophoresis has a wider IL range than IC enabling both water miscible and immiscible samples to be studied, but dilution of the sample was still necessary. In this case methanol was used. ${ }^{21}$ ICP-MS provides a highly sensitive method for water miscible samples only. For water insoluble samples, the method became unreliable. ${ }^{20}$ Similar issues were found with chloride sensitive electrodes where an LOQ $\sim 20 \mathrm{ppm}$ was only found for water miscible samples. ${ }^{6,13}$ The electrochemical methods allow the analysis of the IL samples in their undiluted form with the analysis on the microfluidic device providing a more economical method with respect to sample waste compared with the macro-scale electrochemical setup. Both the macro- and microscale set-ups result in similar LOQ values; however, as demonstrated by the need to dilute the $\left[\mathrm{P}_{666,14}\right]\left[\mathrm{NTf}_{2}\right]$ IL to a small extent, some limitations with respect to viscosity are present with the electrochemical method. The electrochemical microfluidic

(40) Brett, C. M. A., Brett, A. M. O. In Electroanalysis, Oxford Chemistry Primers, No. 64; Oxford University Press: Oxford, 1998. 
device allows the versalitility and similar LOQ of capillary zone electorphoresis and, to some extent, IC but uses a smaller volume of IL and offers a nondestructive methodology.

\section{CONCLUSIONS}

An automated microfluidic electrochemical device has been demonstrated which can measure the halide content of a wide range of hydrophobic and hydrophilic ILs to levels $<20 \mathrm{ppm}$. As well as the electrochemical cell, the microfluidic device incorporates a mixer chip which enables rapid calibration of the device, and the mixing has been shown to be reproducible even with the highest viscosity ILs tested. A chemical cleaning protocol was established using a high concentration of chloride in the IL to produce reproducible electrode surfaces. In comparison with many other techniques used to measure halide, the electrochemical method is versatile and does not require sample pre-treatment before measurement except for high viscosity samples. By utilizing the microfluidic device, the sample size may be reduced compared with the macro-scale electrochemical setup, and the time between samples reduced to $15 \mathrm{~min}$ which includes the time taken to clean the electrodes, as well as the injection and analysis.

\section{ACKNOWLEDGMENT}

This work has been supported by the U.K. Engineering \& Physical Sciences Research Council (EPSRC) under grants EP/ D03826X/1, EP/D038294/1 and EP/D038995/1.

Received for review November 13, 2008. Accepted December 29, 2008.

AC802406K 